\title{
Yenidoğan ünitesine sarılık nedeniyle yatırılan bebeklerin klinik ve laboratuvar özellikleri ve risk faktörlerinin araştırılması
}

\section{Investigation of risk factors and clinical and laboratory characteristics of infants hospitalized in neonatal unit due to jaundice}

\author{
Alaaddin Yorulmaz, ${ }^{1}$ Mehmet Yücel, ${ }^{2}$ Sadiye Sert, ${ }^{2}$ Suna Özdem, ${ }^{2}$ Hasan Arif İstanbullu ${ }^{2}$ \\ Selçuk Üniversitesi Tıp Fakültesi, Çocuk Sağlığı ve Hastalıkları Anabilim Dalı, Konya, Turkey \\ Beyhekim Devlet Hastanesi, Çocuk Sağlığı ve Hastalıkları Kliniği, Konya, Turkey
}

\section{Özet}

Amaç: Bu çalışmada hiperbilirübinemi nedeni ile yatırılan sağlıklı term bebeklerin klinik ve laboratuar özellikleri, indirekt hiperbilirübinemi açısından günümüz risk faktörlerinin belirlenmesi ve bu sorunun bölgemizdeki durumunun gözden geçirilmesi amaçlandı. Gereç ve Yöntem: Bu çalışma; Ocak 2014-Ocak 2016 yılları arasında, Konya Beyhekim Devlet Hastanesi Çocuk Sağlığı ve Hastalıkları Kliniği, Yenidoğan Yoğun Bakım Ünitesine tedavi amacıyla yatırılmış olan 240 indirekt hiperbilirubinemili yenidoğan bebek ile hasta kayıtlarından alınan bilgiler ışığında geriye dönük olarak yapıldı. Hasta dosyasından; cinsiyet, doğum tartısı, hastaneye yatıııldığındaki tartı, sarılığın başlangıç günü, kaçıncı gün yatırıldığı, etyolojik etmenler ile ilgili bilgiler geriye dönük olarak toplandı.

Bulgular: Değerlendirmeye alınan 240 hastanın 132'si (\%55.0) erkek, 108'i (\%45.0) kız idi. Hastaların ortalama doğum ağırlıkları $3046.94 \pm 422.71 \mathrm{gr}$ olup, 29 (\%12.08) hasta 2500 gramın altında idi. Yatışta vücut ağırlıkları ortalama $3094.25 \pm 471.02$ gr idi. Olguların \%7.5'i geç preterm bebeklerdi. Hastalara tanı konulduğu yaş $4.95 \pm 2.29$ gün idi.

Sonuç: İndirekt hiperbilirubinemi, gelişmiş yöntemler ve tedavilere rağmen günümüz yenidoğan acil yaklaşım pratiğinde halen güncelliğini ve önemini korumaktadır.

Anahtar Sözcükler: Hiperbilirubinemi; risk etmenleri; yenidoğan.

$\mathrm{H}$ perbilirubinemi, yenidoğan döneminin önemli ve sık karşılaşılan sorunlarından birisidir. Yenidoğan sarılığı, "hem" katabolizmasının son ürünü olan indirekt bilirübinin depolanmasına bağı olarak cilt ve skleraların sarı renge boyanmasıdır. Yenidoğan döneminde çok sık görülmesi, uygun tedavi yapılmadığı zaman kalıcı nörolojik hasara neden olan kernikteru-

\begin{abstract}
Introduction: In this study, we aimed to determine the clinical and laboratory characteristics of healthy term babies admitted to our hospital with hyperbilirubinemia, today's risk factors in terms of indirect hyperbilirubinemia and, to review the situation of this problem in our region. Methods: In this study, medical records of 240 newborn infants admitted to Neonatal Intensive Care Unit, Children's Health and Diseases Clinic, Konya Beyhekim State Hospital, with indirect hyperbilirubinemia, and hospitalized for treatment between January 2014 and January 2016, were analyzed, retrospectively. Information regarding gender, birth weight, weight at admission, date of onset of jaundice, which day the patient hospitalized, etiologic factors were collected from patient's medical records, retrospectively.

Results: Of the 240 patients who were evaluated, 132 (55.0\%) were male and 108 (45.0\%) were female. The mean birth weights of the patients were $3046.94 \pm 22.71 \mathrm{~g}$ and 29 (12.08\%) patients were below $2500 \mathrm{~g}$. The average body weight of patients at admission was $3094.25 \pm 471.02 \mathrm{gr}$. Seven percent of the cases were late preterm infants. The ages at diagnosis was $4.95 \pm 2.29$ days.

Discussion and Conclusion: Indirect hyperbilirubinemia, despite advanced methods and treatments, is still an updated and important problem in today's neonatal emergency practice.

Keywords: Hyperbilirubinemia; risk factors; newborn.
\end{abstract}

sa sebep olabilmesi nedeniyle uzun yıllar çocuk hekimlerin önemli sorunlarından biri olmuştur. ${ }^{[1]}$ Sağlıklı term bebeklerin \%50-70'inde, preterm bebeklerin \%80'inde sarılık görülmektedir. $^{[2,3]}$ Kernikterus bildirilen ülkeler arasında dünyada Amerika Birleşik Devletleri (\%27) ilk sırayı alırken Singapur (\%19) ikinci sırada yer almaktadır. ${ }^{[4]}$ Türkiye'nin (\%16) üçüncü sırada bulun-

Corresponding (illetişim): Alaaddin Yorulmaz, Selçuk Üniv. Tıp Fak., Çocuk Sağlığı ve Hast. Anabilim Dalı, Konya, Turkey 
ması ülkemizde yenidoğan sarılığı üzerine daha fazla araştırma yapılması gerektiğini düşündürmektedir. ${ }^{[4]}$

Mortalite ve morbiditeyi azaltmak için erken tanı ve uygun tedavi ile mümkün olması nedeniyle yenidoğan sarılığı günümüzde halen önemini korumaktadır. ${ }^{[5]} \mathrm{Hem}$ term hem de preterm bebeklerdeki bu ortak problem karşısında, sarılığın nedeni, uygulanacak tanı ve tedavi programı konusunda hızlı bir değerlendirme yapma zorunluluğu vardır. Yüksek bilirübin düzeyleri için risk faktörlerinin önceden saptanması, sarılık gelişen bebeklerde erken tanı ve tedavi için yol göstereceğinden hiperbilirübinemiye bağlı komplikasyonların gelişimini azaltacaktır.

Bu çalışmada hiperbilirübinemi nedeni ile yatırılan sağlıkı term bebeklerin klinik ve laboratuar özellikleri, indirekt hiperbilirübinemi açısından günümüz risk faktörlerinin belirlenmesi ve bu sorunun bölgemizdeki durumunun gözden geçirilmesi amaçlandı.

\section{Gereç ve Yöntem}

Bu çalışma; Ocak 2014-Ocak 2016 yılları arasında, Konya Beyhekim Devlet Hastanesi Çocuk Sağlığı ve Hastalıkları Kliniği, Yenidoğan Yoğun Bakım Ünitesine tedavi amacıyla yatırılmış olan 240 indirekt hiperbilirubinemili yenidoğan bebek ile hastaların elektronik kayıtlarından elde edilen bilgiler ışığında retrospektif olarak yapıldı.

Çalışmaya alınan hastaların verileri önceden oluşturulan sarılık bebek takip formuna kaydedildi. Cinsiyet, doğum tartısı, hastaneye yatış tartısı, gestasyon yaşı, tanı yaşı, sarılığın başladığı gün, doğum şekli (normal vajinal doğum, sezaryen), eşlik eden diğer yakınmalar, etyolojik faktörler, yatış esnasındaki direkt ve indirekt bilirubin seviyeleri $(\mathrm{mg} / \mathrm{dl})$, fototerapi uygulama süresi (saat) ve yattığı gün süresi ile ilgili bilgiler elde edildi.

Çalışmaya kadın hastalıkları ve doğum servisinde doğan ve annelerin yanında bebeklerin günlük takibi sırasında sarılık tespit edilen bebekler, sağlam çocuk polikliniğinde sarılık tespit edilen bebekler ve sarılık nedeniyle hastanemize sevk edilen bebekler dahil edildi. Gestasyon yaşına göre 36 haftadan küçük olan bebekler çalışmadan çıkarıldı. Ayrıca direkt hiperbilirübinemili, asfiksi, doğuştan anomalisi, solunum yetmezliği, metabolik hastalık düşünülen ve bir başka merkeze sevk edilen bebekler çalışmaya alınmadı.

Gebelik haftaları (GH) son adet tarihine göre hesaplandı. Son adet tarihi bilinmeyen bebeklerde ilk 48 saat içinde başvuranlarda Dubowitz skorlamasına, 48 saatten sonra ise klinik muayene bulgularına göre hesaplandı. Geç preterm bebek 34 gebelik haftasını tamamlamış, 37 gebelik haftasını tamamlamamış yenidoğanlar (238-259 gün) olarak tanımlanmıştır.

Yenidoğan servisine indirekt hiperbilirübinemi nedeniyle yatırılan hastalardan uygun tüplere alınan kan örneklerinden hastanemiz biyokimya laboratuarında, total ve direkt bilirubin düzeyi ölçüldü. Amerikan Pediatri Akademisi'nin önerilerinde bildirilen total serum bilirübin düzeylerine göre fototerapi uygulama kararı alındı. ${ }^{[6]}$ Mediprema marka blue-light 400-500 nm dalga boyu fototerapi cihazı kullanıımıştır.
Çalışmada yer alan her hastada kan grubu, serum indirekt ve direkt bilirubin düzeyi, tam kan sayımı, tam idrar tetkiki, retikülosit sayısı, direkt Coombs testi yapılmış olma şartı arandı. Serbest triiodotironin (sT3) ve tiroksin (sT4), tiroid stimülan hormon (TSH) seviyesi (radioimmunoassay yöntemi ile) ölçülen hastalar da ayrıca değerlendirildi. Doğumdan sonraki yedinci günde alınan serum örneklerinde TSH seviyesinin $>20$ $\mathrm{IU} / \mathrm{ml}$, total T4 seviyesinin $<6 \mathrm{mcg} / \mathrm{dl}$ ya da sT4 seviyesinin $<0.9$ $\mathrm{ng} / \mathrm{dl}$ olması konjenital hipotiroidi için anlamlı kabul edildi. ${ }^{[7]}$ Klinik kuşku varlığında kan kültürü, idrar kültürü, göbek kültürü, intrauterin enfeksiyonlar ile ilgili serolojik tetkikler yapılmış olan hastalar kaydedildi.

Çalışmanın etik kurul onayı Selçuk Üniversitesi etik kurul komitesinden alındı.

\section{İstatistiksel Analiz}

Çalışmada elde edilen veriler, istatistiksel analizleri için SPSS 21.0 (IBM SPSS statistics 21) paket bilgisayar programı kullanıldı. Tanımlayıcı veriler istatistiksel metodları Ortalama \pm Standart sapma ile gösterildi. Verilerin normal dağılıma uygun olup olmadığını ortaya koymak amacıyla Kolmogorow-Smirnov ve Shapiro-Wilk normallik testleri yapıldı. Parametrik veriler Student T-testi, parametrik olmayan veriler ki-kare testi, Mann-Whitney U testi ile yapıldı. Grupların karşılaştıııımasında Kruskal-Wallis testi uygulandı. Anlamlılık $p<0.05$ düzeyinde değerlendirildi.

\section{Bulgular}

Değerlendirmeye alınan 240 hastanın 132'si (\%55.0) erkek, 108 'i (\%45.0) kız idi. E/K oranı 1.22 idi. Hastalarımızın demografik özellikleri Tablo 1'de gösterilmiştir. Hastaların ortalama doğum ağırlıkları 3046.94 $2422.71(2000-4100)$ gr olup, 29 (\%12.08) hasta 2500 gramın altında idi. Yatışta vücut ağırlıkları ortalama 3094.25 \pm 471.02 gr (2100-4200) idi. Hastaların 119 'unun (\%49.6) normal spontan vajinal doğum, 121'sinin (\%50.4) ise sezaryen doğum ile doğdukları saptandı. Gestasyonel yaşları ortalama $38.86 \pm 1.35$ hafta olarak saptandı. Olguların \%7.5'i geç preterm (gebelik haftası <37) bebeklerdi. Hastalara tanı konulduğu yaş $4.95 \pm 2.29$ gün (1-13) idi. Yenidoğan bebeklerin \%24.2'sinde $(n=58)$ ilk 24 saat içinde sarılık tespit edildi. Bebeklerin hastanede yatış süresi ortalama $3.05 \pm 2.29$ gün (1-9) olup fototerapi uygulama süresi ortalama $32.56 \pm 13.84$ saat (12-96) idi. Bebeklerde sarılık yakınmasına ek olarak; \%25.83'ünde $(n=62)$ emmeme, $\% 10$ 'unda $(n=24)$ uyuklama, \%5'inde $(n=12)$ huzursuzluk bulunmaktaydı.

Hastaların \%25.41'inde ( $n=61)$ ABO grup uyuşmazlığı, \%6.25'inde ( $n=15)$ Rh grup uyuşmazlığı, \%2.5'inde $(n=6)$ $\mathrm{Rh}+\mathrm{ABO}$ grup uyuşmazlığı mevcuttu (Tablo 2). Hastaların 7'sinde retikülositoz ve anemi ile karakterize hemoliz tespit edildi. Direkt coombs testi bu olgularda pozitif bulundu. Bu hastaların 4'ünde $A B O$ uygunsuzluğu, 3 'ünde $A B O+R h$ uygunsuzluğu mevcuttu. Üç hastaya intravenöz immünglobülin tedavisi uygulandı. Hastaların \%20'sinde $(n=48)$ tam idrar tetkiki 
Tablo 1. Hastalarımızın demografik özellikleri

\begin{tabular}{|c|c|c|}
\hline & $\mathbf{n}$ & $\%$ \\
\hline \multicolumn{3}{|l|}{ Cinsiyet } \\
\hline Erkek & 132 & 55.0 \\
\hline $\mathrm{KIz}$ & 108 & 45.0 \\
\hline \multicolumn{3}{|l|}{ Doğum şekli } \\
\hline NSV & 119 & 49.6 \\
\hline $\mathrm{C} / \mathrm{S}$ & 121 & 50.4 \\
\hline \multicolumn{3}{|l|}{ Gestasyonel yaş } \\
\hline 36 & 18 & 7.5 \\
\hline 37 & 19 & 7.9 \\
\hline 38 & 46 & 19.2 \\
\hline 39 & 78 & 32.5 \\
\hline 40 & 53 & 22.1 \\
\hline 41 & 26 & 10.8 \\
\hline \multicolumn{3}{|l|}{ İlk 24 saat içinde sarılık } \\
\hline Hayır & 182 & 75.80 \\
\hline \multirow[t]{2}{*}{ Evet } & 58 & 24.20 \\
\hline & \multicolumn{2}{|c|}{ Ortalama $\pm S S$ (Min-Maks) } \\
\hline Doğum tartısı (gram) & \multicolumn{2}{|c|}{$3046.94 \pm 422.71(2000-4100)$} \\
\hline Yatış tartısı (gram) & \multicolumn{2}{|c|}{$3094.25 \pm 471.02(2100-4200)$} \\
\hline Tanı konulduğu yaş (gün) & \multicolumn{2}{|c|}{$4.95 \pm 3.01(1-13)$} \\
\hline Yatı̧̧ süresi (gün) & \multicolumn{2}{|c|}{$3.05 \pm 2.29(1-9)$} \\
\hline Fototerapi süresi (saat) & \multicolumn{2}{|c|}{$32.56 \pm 13.84(12-96)$} \\
\hline
\end{tabular}

NSV: Normal spontan vajinal ; doğum; C/S: Sezaryen doğum; SS: Stadart sapma; Min: Minimum; Maks: Maksimum.

\section{Tablo 2. Yenidoğan sarılığın etyolojik nedenleri}

\begin{tabular}{lcc} 
& $\mathbf{n}$ & $\%$ \\
\hline ABO uygunsuzluğu & 61 & 25.41 \\
Rh uygunsuzluğu & 21 & 8.75 \\
ABO + Rh uygunsuzluğu & 6 & 2.50 \\
İdrar yolu enfeksiyonu & 48 & 20.00 \\
Beslenme yetersizliği & 41 & 17.10 \\
Prematürite & 18 & 7.50 \\
Sepsis & 20 & 8.30 \\
Polisitimi & 16 & 6.70 \\
Hipotiroidi & 6 & 2.50 \\
Sefal hematom & 5 & 2.90 \\
Down sendromu & 4 & 1.70 \\
Omfalit & 3 & 1.25 \\
G6PD eksikliği & 2 & 0.83 \\
Nedeni belirlenemeyen & 38 & 15.80 \\
\hline
\end{tabular}

ve idrar kültürü ile tanı konulmuş üriner sistem enfeksiyonu tespit edildi. Hastaların 14'ünde mikroorganizma (6 hastada E. Coli, 4 hastada Klebsiella spp, 2 hastada enterobakter, 1 hastada psödomonas spp) üredi. Hastaların \%17.1'inde $(n=17)$ beslenme yetersizliği (\%10 ve üzeri kilo kaybı) tespit edildi. Bu
Tablo 3. Hastalarımızın laboratuvar özellikleri

\begin{tabular}{|c|c|}
\hline & Ortalama $\pm S S$ \\
\hline WBC & $12.33 \pm 3.70$ \\
\hline $\mathrm{Hgb}$ & $17.54 \pm 2.29$ \\
\hline Htc & $50.31 \pm 6.56$ \\
\hline MCV & $100.94 \pm 5.20$ \\
\hline RDW & $16.69 \pm 1.70$ \\
\hline Nötrofil sayısı & $5.04 \pm 3.33$ \\
\hline Lenfosit sayısı & $5.10 \pm 1.55$ \\
\hline PLT & $326.06 \pm 109.14$ \\
\hline MPV & $10.41 \pm 0.95$ \\
\hline PDW & $11.94 \pm 2.09$ \\
\hline РCT & $0.33 \pm 0.10$ \\
\hline P-LCR & $27.55 \pm 7.70$ \\
\hline Yatış Total Bilirübin düzeyi & $17.62 \pm 2.77$ \\
\hline Yatış Direkt Bilirübin düzeyi & $0.97 \pm 0.21$ \\
\hline Çıkış Total Bilirübin düzeyi & $9.63 \pm 1.64$ \\
\hline Üre & $21.96 \pm 14.68$ \\
\hline Kreatinin & $0.39 \pm 0.23$ \\
\hline AST & $49.50 \pm 22.64$ \\
\hline ALT & $17.55 \pm 10.09$ \\
\hline $\mathrm{Na}$ & $140.23 \pm 4.83$ \\
\hline K & $4.93 \pm 0.62$ \\
\hline $\mathrm{Ca}$ & $9.87 \pm 0.81$ \\
\hline Total protein & $5.49 \pm 0.52$ \\
\hline Albümin & $3.56 \pm 0.32$ \\
\hline $\mathrm{TSH}$ & $8.52 \pm 10.66$ \\
\hline FT3 & $4.75 \pm 7.43$ \\
\hline FT4 & $1.56 \pm 0.64$ \\
\hline
\end{tabular}

SS: Standart sapma.

hastalara parenteral sıvı tedavisi başlandı. Hastaların 20'sinde (\%8.3) etiyolojik etmen olarak klinik ve/ya da laboratuvar bulgularıyla (periferik yayma, akut faz reaktanları vb) sepsis tanısı konulmuş olup, bunların kan kültürlerinde 3 hastada E. Coli, iki hastada Klebsiella spp, bir hastada metisiline duyarlı S. aureus, bir hastada metisiline dirençli S. aureus üremişti. Diğer olguların kan kültürlerinde üreme saptanmadı. Üç hastada göbekte eritem ve akıntı mevcuttu. Steril şartlarda alınan göbek kültürlerinde iki olguda staphilococcus aureus, bir olguda staphilococcus epidermidis üredi. Olguların $\% 0.83$ 'ünde $(n=2)$ G6PDH aktivitesi eksikliği vardı (G6PDH: 2.4 ve $1.2 \mathrm{U} / \mathrm{g} \mathrm{Hb}$; Ref: 6.5-14.4 U/g Hb). Hastaların tamamının tedavisinde, fototerapi uygulanmış olup kan değişimi uygulanması gerekmemiştir. Fototerapi ile ilgili komplikasyon gelişmemiştir.

Risk faktörleri açısından erkek cinsiyette daha sık görüldüğü tespit edildi (erkeklerde \%55, kızlarda \%45). Ancak total serum bilirübün düzeyleri cinsiyet göre karşılaştırıldığında istatiksel olarak anlamlı bir ilişki bulunmadı $(p=0.254)$. Yenidoğan bebekler fizyolojik tartı kaybı olanlar (doğum kilosuna göre $<\% 10)$ ve patolojik tartı kaybı olanlar $(\geq \% 10)$ olmak üzere 
ikiye ayrıldı. Patolojik olarak kilo kaybeden bebek sayısı 41 (\%17.1) idi. Bu iki grup arasında total bilirübin düzeyleri karşılaştırıldığında istatistiksel olarak anlamlı bulunmadı ( $p=0.467)$. Doğum şekli ile bilirübin düzeyi arasındaki ilişki karşılaştırıldığında normal spontan yolla doğan bebeklerde total bilirübin düzeyi sezaryan ile doğan bebeklere göre daha yüksek tespit edildi (sırasıyla; ortalama total bilirübin düzeyi: 18.17 \pm 2.22 , $17.07 \pm 3.14)$ ve istatistiksel olarak anlamlı bulundu $(p=0.002)$.

Başvuru sırasında saptanan ortalama serum total bilirubin değeri 17.62 \pm 2.77 (7.1-24.1) mg/dl idi (Tablo 3). En yüksek total bilirubin değeri $24.1 \mathrm{mg} / \mathrm{dl}$ ile $A B O$ uygunsuzluğu+ Rh uygunsuzluğu olan term bir bebeğe aitti. Ortalama direkt bilirubin değeri $0.97 \pm 0.21 \mathrm{mg} / \mathrm{dl}$ olup olguların tümünde $2 \mathrm{mg} / \mathrm{dl}$ 'nin altında saptandı. Hastaların hastaneden taburcu olurken ortalama total bilirübin düzeyi $9.63 \pm 1.64 \mathrm{mg} / \mathrm{dl}$ idi.

\section{Tartışma}

Hem term hem preterm bebeklerde görülen sarılık ortak bir sorun olmaya devam etmektedir. ${ }^{[7]}$ Sağlıklı term yenidoğanların \%97'sinde biyokimyasal (1 mg/dl), \%65'inde klinik (5 mg/ dl) olarak hiperbilirubineminin varlığı tespit edilmiştir. ${ }^{[7]}$ Sağlıklı bebeklerin yaklaşık \%6-7'sinde indirekt bilirubin düzeyi 13 mg/dl, yaklaşık \%3'ünde indirekt bilirübin düzeyi 15'in mg/ dl üzerinde tespit edilir. Serum bilirubininin oksidatif hasarlara karşı koruyucu, antioksidan özellikte bir madde olduğu bilinmektedir. Bununla birlikte hiperbilirubineminin ciddi bir sonucu olan kernikterus dışında, düşük bilirubin seviyelerinde de hafif nörotoksisite ve mental geriliğe yol açabileceği de bildirilmiştir. ${ }^{[7,8]}$ Bunun aksini savunan ve mental durum ile psikomotor gelişimle, serum bilirubin tepe değerleri arasında ilişki olmadığını bildiren yayınlar da vardır. Çalışmamızda ağır olgular bir üst merkeze sevk edildiğinden hastaların verilerine ulaşılamadığı için morbidite oranı yönünden yorum yapılamadı.

Yenidoğan bebeklerde ilk 24 saatte ortaya çıkan sarılık için risk faktörleri olarak kan grubu uyuşmazlığı, G6PD eksikliği, polisitemi, sefal hematom, diyabetik anne bebeği, aşırı tartı kaybı, anne sütüyle beslenme, erkek cinsiyet, rakım, fototerapi almış kardeş öyküsü, trizomi 21, oksitosin indüksiyonu gösterilmektedir. ${ }^{[9]}$ Ayrıca hiperbilirübineminin gelişiminde kalıtsal özelliklerin ve çevresel koşulların önemli rol oynadığı, risk faktörlerinin her toplum için farklı olduğu bilinmektedir. Bu yüzden her toplum için risk faktörlerinin ve bilirübin eğrilerinin ayrı ayrı tanımlaması gerektiği vurgulanmaktadır. ${ }^{[2,3,10,11]}$

ABO uygunsuzluğu, hemolitik hastalıklar içinde, hiperbilirubineminin en sık nedenidir. Pasif antikor geçişinin rol oynaması nedeniyle birinci gebelikte de gerçekleşme olasılığı yüksektir.

[7] Bolat ve ark.nın yaptıkları çalışmada indirekt hiperbilirübinemi sebebiyle fototerapi için hastaneye yatırılan bebeklerin \%29.2'sinde ABO uyuşmazlığı, \%6.4'ünde Rh uyuşmazlığı saptamışlardır. ${ }^{[12]}$ Çalışmamızda hastaların \%25.41'inde ABO grup uyuşmazlığı, \%8.75'inde Rh grup uyuşmazlığı, \%2.50'inde $\mathrm{Rh}+\mathrm{ABO}$ grup uyuşmazlığı vardı.

$A B O$ ve Rh uygunsuzluklarında direkt ya da indirekt Coombs testleri tanı için kullanılabilir. Direkt Coombs testi özellikle Rh uygunsuzluklarında yüksek pozitiflik verirken, ABO uygunsuzluklarında zayıf reaksiyondan dolayı çoğu kez negatiftir ya da zayıf pozitiflik verir. İndirekt Coombs testleri teknik olarak daha zor test olmasına karşın daha duyarlıdır. Bu çalışmadaki olgulara direkt coombs testi bakılmış olup, 4 hastada $A B O$ uygunsuzluğu, 3 hastada $\mathrm{ABO}+\mathrm{Rh}$ uygunsuzluğu bulunan 7 olguda pozitif sonuç saptanmıştır. 3 hastaya bu nedenle intravenöz immünglobülin tedavisi uygulandı.

Yenidoğan sarılığı erkek bebeklerde daha sık görüldüğü bilinmektedir. ${ }^{[13,14]}$ Çalışmamızda hastaların \%55'ini erkek bebekler oluşturuyordu. Hiperbilirübinemi düzeyi ile cinsiyet açıdan karşılaştırıldığında istatiksel olarak anlamlı bir fark tespit edilmedi. Erkeklerde hiperbilirübinemi daha sık tespit edilmesine rağmen, yüksek bilirübin düzeyleri için bir risk faktörü olarak değerlendirilmedi.

Yapılan bir çalışmada total bilirübin düzeyinin $25 \mathrm{mg} / \mathrm{dl}$ üzerine çıkmasındaki en önemli risk faktörlerin ciltte ekimoz, geatasyonel yaş, aile öyküsü varlığı ve anne sütü ile beslenme olduğu belirtilmiştir. ${ }^{[15]}$ İnfant beslenmesinde sınırda tartı kaybı olan bebeklerde yüksek bilirübin varlığında anne sütüyle beslenme ile birlikte formüla mama ile desteklenmesinin riski azaltacağını bildirmişlerdir. Yine aynı çalışmada infantlarda \%10'dan fazla ağırlık kaybının varlığı bilirübin düzeyinin 25 mg/dl üzerine çıkmasında önemli bir belirleyici risk faktörü olarak kabul edilmemiş ve bunun nedeninin hızlı hidrasyona ve beslenme desteğine bağlanmıştır. ${ }^{[15]}$ Çalışmamızda bütün annelere emzirme eğitimi verilmiş, sadece ağırlık kaybının $\% 10$ ve daha fazla olan bebeklere anne sütüne ilave olarak mama desteği önerilmiştir.

Yenidoğan bebeklerde kilo kaybı sarılık için önemli bir risk faktörüdür. ${ }^{[16-18]}$ Patolojik düzeyde ağırlık kaybı, bebeğin yeterli beslenmediğini ve dolayısıyla enterohepatik bilirübin döngünün arttığını gösterir. Bir gram yaş mekonyum 1 mg bilirübin içerir. Yetersiz beslenen yenidoğan bebeklerde mekonyum çıkarmanın yavaşlaması ve sıklığının azalması sarılığın artmasına neden olmaktadır. Bebeklerin sık sık emzirilmesi, günlük yeterli düzeyde sıvı ve kalori ihtiyacının sağlanması bu yüzden önemlidir. Salas ve ark.nın yaptıkları çalışmada yenidoğanlarda tartı kaybının fazla olması ile hiperbilirübinemi arasında kuvvetli ilişki olduğunu tespit etmişlerdir. ${ }^{[19]}$ Yapılan çalışmalarda indirekt hiperbilirübinemi nedeniyle hastaneye yatırılan yenidoğan bebeklerde Okan ve ark. \%11.1'inde, Çayönü ve ark. \%8'inde patolojik kilo kaybı tespit etmişlerdir. ${ }^{[20,21]}$

Niestijl ve ark.nın çalışmasında hiperbilirübinemi gelişmesini önlemek için fizyoloik ağırlık kaybı olan bebeklerde anne sütü ile sık sık emzirmelerini ve patolojik ağırlık kaybı olanlarda ise anne sütüne ek olarak mama desteği önermişlerdir. ${ }^{[16]}$ Ebbesen ve ark.nın ikiz bebeklerin biliüubin düzeylerinin karşılaştırıldığı çalışmasında tartı kaybı ile bilirübin düzeyi arasında yakın iliş̧i olduğunu tespit etmişlerdir. ${ }^{[22]}$ Kalıtsal ve çevresel koşulları aynı olan ikiz bebeklerde yapılan bu çalışmada, tartı kaybının bilirübin yükselmesine sebep olan bir risk faktörü olduğunu düşündürmektedir. Çalışmamızda indirekt hiper- 
bilirübinemili hastaların \%17,10'unda beslenme yetersizliği saptadık ve bu hastalara anne sütüne ilaveten parenteral sıvı tedavisi verilmiştir.

Prematüre bebeklerde termlere göre bilirubin artışı daha yavaş hızda olmakta, ancak daha uzun sürede, genellikle daha yüksek düzeylere ulaşmaktadır. ${ }^{[23]}$ Olgularımızın \%7.5'ini geç preterm bebekler oluşturmaktaydı. Geç preterm bebeklerin \%44.4'ünde beslenme yetersizliği tespit edildi. Bu yüzden preterm bebeklerin ağılık takipleri daha yakından izlenmesi gerekliliğini düşündürmektedir.

Üriner sistem enfeksiyonunun ilk bulgusu sarılık olarak karşımıza çıkabilir. Yılmaz ve ark.nın yaptıkları çalışmada indirekt hiperbilirübinemi ile yatırılan bebeklerin \%9.9'unda idrar yolu enfeksiyonu bulmuşlar ve bu bebeklerin \%86.4'ünde sarılıktan başka klinik bulgu saptamamışlar. ${ }^{[24]}$ Yine aynı çalışmada idrar yolu enfeksiyonu olan bebeklerde idrar yolu enfeksiyonu olmayanlara göre sarılığın daha geç ortaya çıktığı, direkt bilirübin düzeyinin daha yüksek olduğu ve ağırlık artışının daha az olduğunu tespit etmişlerdir. ${ }^{[24]}$ Tan ve ark.nın geç prematüre 222 indirekt hiperbilirübinemili yenidoğan bebek üzerinde yaptıkları çalışmasında hastaların \%22.7'sinde yetersiz beslenme, \%8.5'inde idrar yolu enfeksiyonu ve $\% 4.05$ 'inde hipernatremik dehidratasyon saptamışlardır. ${ }^{[25]}$ Omar ve ark. indirekt hiperbilirübinemi nedeniyle yatırılan 152 hastanın \%21.1'inde idrar kültüründe üreme tespit etmişlerdir. ${ }^{[26]}$ Bilgen ve ark.nın 102 hasta ile yaptıkları çalışmada sarılıktan başka semptomu olmayan hastaların \%8'inde idrar yolu enfeksiyonu saptamışlardır. ${ }^{[27]}$ Garcia ve ark. ise 160 hastanın \%7.5'inde idrar kültüründe üreme saptamışlardır. ${ }^{[28]}$ Shahian ve ark. ise ilk yedi gün içinde semptomsuz indirekt hiperbilirübinemili hastaların \%12.5'inde idrar yolu enfeksiyonu tespit etmişlerdir. ${ }^{[29]}$ Çalışmamızda ise hastalarımızın \%20'sinde üriner sistem enfeksiyonu tespit edilmiş olup \%5.83'ünde idrar kültürü ile kanıtlanmış idi.

Yenidoğan bilirübin yüksekliği için bakteriyel septisemide önemli risk faktörleri arasında gösterilmektedir. Maisels MJ ve ark.nın 306 sarılıklı yenidoğanı kapsayan çalışmasında bakteriyemi ya da sepsisin yenidoğan sarılıklarında risk oluşturma etkisine bakılmış ve risk oluşturmadığı sonucu ortaya çıkmıştır. ${ }^{[30]}$ Buna karşın birçok çalışma bunun aksini vurgulamaktadır. Nitekim Nijerya'da yapılan bir çalışmada preterm bebeklerde septiseminin, yüksek bilirubin düzeyi ve yüksek mortalite ile ilişkili olduğu bildirilmiştir. ${ }^{[31]}$ Ülkemizde yapılan çalışmalarda ise Kılıç ve ark. 140 hastanın \%27.14'ünde sepsis, \%1.42'sinde akciğer enfeksiyonu, \%12.14'ünde omfalit, Tekinalp ve ark.hastaların \%7.2'sinde sepsis, omfalit, pnömoni tespit etmişlerdir. ${ }^{[32,33]}$ Ergür ve ark. uzamış sarılıklarda sepsis ve diğer enfeksiyonların oranını \%11 olarak saptamıştıı. ${ }^{[34]}$ Tekinalp ve ark.nın yaptıkları çalışmada ise toplam enfeksiyon oran \%12.1 iken sepsis oranı \%3.6 olarak saptanmıştıı. ${ }^{[33]}$ Arsan ve ark. enfeksiyon oranını \%20.8, Aygün ve ark. ise \%18.4 olarak saptamışlardır. $^{[3,36]}$ Son iki çalışmada olguların tamamının idrar yolu enfeksiyonu olması dikkat çekicidir. Çalışmamızda sepsis \%8.30 olarak tespit edilmiştir. Bu da hiperbilirübinemi etyolojisinde sepsisin önemli bir neden olduğunu düşündürmektedir.
Primer konjenital hipotiroidi uzamış sarılıkta önemli bir nedendir. Yenidoğan döneminde yaklaşık 1:3000 ile 1:4000 oranında görülür. ${ }^{[3]]}$ Ülkemizde yapılan değişik çalışmalarda uzamış sarılıkta oranı \%1.2-6.0 olarak saptanmıştır. ${ }^{[33,34]}$ Ankara'da yapılan ve 30097 yenidoğanı kapsayan bir pilot çalışmada konjenital hipotiroidi için 1:2736 gibi yüksek bir değer saptanmıştır. ${ }^{[38]}$ Çalışmamızda ise hiperbilirübinemi yapan neden içinde \%2.50'sinde primer konjenital hipotiroidi tanısı konulmuştur. Erken tanı ve tedavinin çok önemli olduğu konjenital hipotiroidi insidansının ülkemizde yüksek olduğu, tarama testlerinin yaygınlaştırılması ve patolojik sarılıklı bebeklerde de araştırılması gerekliliği açıkça görülmektedir.

Dünyada yaklaşık 400 milyon kişiyi etkileyen Glukoz 6 fosfat dehidrogenaz (G6PD) enzimi eksikliği en sık rastlanan enzim defektidir. ${ }^{[39]}$ Oksidan maddelerle karşılaşıldığında enzim eksikliği olanlarda hemolitik anemiye neden olmaktadır. Hastalığın sıklığı coğrafi bölgelere göre değişmekte olup, Akdeniz ülkelerinde görülme oranı yüksektir. G6PD eksikliği oranı uzamış sarılıkları inceleyen bir çalışmada \%12.00 bulunmuş iken, bir başka çalışmada ise $\% 1.20$ olarak saptanmıştır. ${ }^{[33,40]}$ Çalışmamızda daha düşük oranda G6PDH eksikliği (\%0.83) saptanmıştır. Bu oranının düşük çıkmasının nedeni hiperbilirubinemi tespit edilen her hastada enzim tayini yapılamadığı içindir.

Etiyoloji saptanamayan sarılık oranı değişik çalışmalarda \%2577 arasında değişen yüksek oranlarda bildirilmiştir. Olguların çoğunda bu durum anne sütü ile bağlantılı olarak değerlendirilmiştir. Çalışmamızda idiopatik sarılık oranı \%15.80 olarak tespit edilmiştir.

\section{Sonuç}

En sık karşılaşılan problemlerden biri olan yenidoğan sarılığı iyi takip ve tedavi ile başarılı sonuçlar elde edilmektedir. Ancak iyi takip edilmediği zaman bilirübin ensefalopati ve kernikterus ile dramatik sonuçlar doğurabilmektedir. $A B O$ uygunsuzluğu hala önemli risk faktörü olmaya devam etmektedir. Birinci basamak hizmetlerinin yaygınlaştırılması ile olumlu sonuçlar elde edileceği umut edilmektedir. Modern perinatoloji çalışmaları ile birlikte önemli risk faktörü olan Rh uygunsuzluğunun eskiye göre azalma görülmektedir. İndirekt hiperbilirübinemi, daha yakın takip ve basit yaklaşımlar ile kalıcı sekel bırakmadan önlenebileceği düşündürmektedir.

Sarılık nedeniyle yatırılan bebeklerin \%94.1'inin doğumunun bir sağlık kuruluşunda olduğu düşünüldüğünde, hastaneden taburcu edilen bebeklerin hiperbilirübinemi gelişmesi yetersiz izlemlerinin olduğunu düşündürmektedir. Yenidoğan bebeklerin tümünde mutlaka taburcu olmadan önce hiperbilirübinemi açısından risk faktörleri değerlendirilmeli ve bu bebekler daha yakından takip edilmelidir. Bölgemizde annelere doğum sonrasında beslenme eğitimi verilmesi sarılık nedeniyle hastaneye yatış oranlarını azaltacağı öngörülebilmektedir. Ayrıca sarılık ile yatırılan bebeklerde idrar yolu enfeksiyonu mutlaka unutulmaması gereken bir risk faktörüdür. 
Sonuç olarak sarılık, modern yöntemler ve tedaviler gelişmesine rağmen günümüzde halen güncelliğini ve önemini korumakta ve ciddiyetle yaklaşımı gerektiren konu olmaya devam etmektedir.

\section{Çıkar çatışması: Bildirilmemiştir.}

\section{Kaynaklar}

1. Tekinalp G. Kan Değişimi. Katkı Pediatri Dergisi 1995;16:744-59.

2. Maisels MJ, Kring EA. Length of stay, jaundice and hospital readmission. Pediatrics 1998;101:995-9.

3. Madam A, MacMahon JR, Stevenson DK. Neonatal Hyperbilirubinemia. In: HW Taeusch, Ballard RA, Gleason CA (eds). Avery's Diseases of Newborn. 8th ed. Philadelphia: Elsevier Saunders; 2005. pp. 1226-9.

4. Ip S, Chung M, Kulig J, O'Brien R, Sege R, Glicken S, et al. and Subcommittee on Hyperbilirubinemia. An evidence-based review of important issues concerning neonatal hyperbilirubinemia. Pediatrics 2004;114:130-53.

5. Maisels MJ. Neonatal jaundice. Pediatr Rev. 2006;27:443-54.

6. American Academy of Pediatrics: Management of hyperbilirubinemia in the newborn infant 35 or more weeks of gestation. Pediatrics 2004;114:297-316.

7. Dağoğlu T, Ovalı F. Yenidoğan Sarılıkları. Ed: Dağoğlu T. İstanbul: Nobel Tıp Kitapevi 2000:441-7.

8. Newman TB, Maisels MJ. Evaluation and treatment of jaundice in the term newborn: a kinder, gentler approach. J Pediatr 1992;144:364-8.

9. Kliegman RM. Nelson pediatrics. In: Ambalavanan N, editor. Jaundice and hyperbilirubinemia in newborn. Philedelphia: 2011. p. 603.

10. MJ Maisels. Jaundice. In: Avery GB, Fletcher MA, MacDonald MG (eds). Neonatology : pathophysiology management of the newborn. 5th ed. Philadelphia: Saunders, 1998:765-819.

11. Huang MJ, Kua KE, Teng HC, Tang KS, Weng HW, Huang CS. Risk factors for severe hyperbilirubinemia in neonates. Pediatr Res 2004;56:682-9.

12. Bolat F, Uslu S, Bülbül A, Cömert S, Güran Ö, Kiray BE, et al. Comparison of $A B O$ and $R h$ incompatibility in neonatal indirect hyperbilirubinemia. ŞEEAH Tıp Bülteni 2010;44:156-61.

13. Riskin A, David M, Peskin B, Tamir A, Vafsi O, Leibovitz Z, et al. The role of umblical cord alpha fetoprotein as a screening tool for neonatal hyperbilirubinemia. Am J Perinatol 2004;21:93-8.

14. Hintz SR, Gaylord TD, Oh W, Fanaroff AA, Mele L, Stevenson DK, et al; NICHD, Neonatal Research Network. Serum bilirubin levels at 72 hours by selected characteristics in breastfed and formula-fed term infants delivered by cesarean section. Acta Paediatr 2001;90:776-81.

15. Kuzniewicz MW, Escobar GJ, Wi S, Liljestrand P, McCulloch C, Newman TB. Risk factors for severe hyperbilirubinemia among infants with borderline bilirubin levels: a nested case-control study. J Pediatr 2008;153:234-40.

16. Niestijl AL, Sauer PJ. Breast feeding during the first few days after birth: sometimes insufficient. Ned Tijdschr Geneeskd
2004;148:504-5.

17. Bertini G, Dani C, Tronchin M, Rubaltelli FF. Is breastfeeding really favoring early neonatal jaundice? Pediatrics 2001;107:41-4.

18. Bertini G, Dani C, Pezzati M, Rubaltelli FF. Prevention of bilirubin encephalopathy. Biol Neonate 2001;79:219-23.

19. Salas AA, Salazar J, Burgoa CV, De-Villegas CA, Quevedo V, Soliz A. Significant weight loss in breastfed term infants readmitted for hyperbilirubinemia. BMC Pediatr 2009;9:82.

20. Okan F, Köymen G, Cevahir E, Nuhoğlu A. Hyperbilirubinemia risk factors and frequency of healthy term infants. Turkiye Klinikleri J Pediatr 2006;15:144-50.

21. Çayönü N, Bülbül A, Uslu S, Bolat F, Güran Ö, Nuhoğlu A. İndirect hyperbilirubinemia changes of newborn babies in the last decade. ŞEEAH Tıp Bülteni 2011;45:85-93.

22. Ebbesen F, Mortensen BB. Difference in plasma bilirübin concentration between monozygotic and dizygotic newborn twins. Acta Paediatr 2003;92:569-73.

23. Pintov S, Kohelet D, Arbel E, Goldberg M. Predictive inability of cord zinc, magnesium and copper levels on the development of benign hyperbilirubinemia in the newborn. Acta Paediatr 1992;81:868-69.

24. Yılmaz H, Öz E, Kibar AE, Peltek N, Kara N, Çakmak F, et al. Management of prolonged icterus of neonates with urinary tract infections. Turkiye Klinikleri J Pediatr 2007;16:186-93.

25. Tan I, Salihoğlu Ö, Demirelli Y, Hatipoğlu S. Clinical and laboratory characteristics and associated risk factors of infants hospitalized in neonatal unit due to indirect hyperbilirubinemia. JCEI/Journal of Clinical and Experimental İnvestigations 2012;3:38-43.

26. Omar C, Hamza S, Bassem AM, Mariam R. Urinary tract infection and indirect hyperbilirubinemia in newborns. N Am J Med Sci 2011;3:544-7.

27. Bilgen H, Ozek E, Unver T, Biyikli N, Alpay H, Cebeci D. Urinary tract infection and hyperbilirubinemia. Turk J Pediatr 2006;48:51-5.

28. Garcia FJ, Nager AL. Jaundice as an early diagnostic sign of urinary tract infection in infancy. Pediatrics 2002;109:846-51.

29. Shahian M, Rashtian P, Kalani M. Unexplained neonatal jaundice as an early diagnostic sign of urinary tract infection. Int J Infect Dis 2012;16:487-90.

30. Maisels MJ, Kring E. Risk of sepsis in newborns with sever hyperbilirubinemia. J Pediatr 1992;90:741-3.

31. Owa J, Dawodu AH. Neonatal jaundice among Nigerian preterm infants. West Afr J Med 1990;9:252-7.

32. Kılıç İ, Ergin $\mathrm{H}$, Çakaloz İ. The evaluation of indirect hyperbilirubinemia cases in newborn period. Turkiye Klinikleri J of Pediatrics 2005; 14:22-5.

33. Tekinalp G, Ergin H, Erdem G, Yurdakök M, Yiğit S. Yenidoğan döneminde uzamış sarılık. 82 vakanın değerlendirilmesi. Çocuk Sağlığı ve Hastalıkları Dergisi 1996;39:441-8.

34. Ergür AT, Murat M, Leylek ÖA, Cevit Ö, İçağasıoğlu D, Gültekin A. Neonatoloji Ünitemizde Uzamış Sarılık Tanısı Alan Yenidoğanların Değerlendirilmesi T Klin Pediatri 1997;6:167-72.

35. Arsan S, Koç E, Uluşahin N, Sönmezışık G, Berberoğlu M. Yenidoğanda uzamış indirekt hiperbilirubineminin etiyolojik yönden incelenmesi. Pediatride Yönelişler 1995;1:14-8.

36. Aygün D, Yaşar F, Güngör S, Yılmaz E, Akarsu S, Kabakuş N 
Yenidoğan Ünitesinde izlediğimiz Uzamış sarılıklı bebeklerin özellikleri. T Klin Pediatri 1998;7:73-7.

37. Giroux B, Metz C, Giroux JD, L de Parscau. Hypothyroidie centrale de decouverte neonatale. Arch Pediatr 1997;4:542-54.

38. Yordam N, Çalikoğlu A, Hatun S, Kandemir N, Oğuz H, Teziz T, Özalp I. Screening for congenital hypothyroidism in Turkey. Eur J
Pediatr 1995;154:614-6.

39. Ruwende C, Hill A. Glucose-6-phosphate deficiency and malaria. J Mol Med 1998;76:581-6.

40. Satar M, Kılınç Y, Tanyeli A, Tok M, Etiz L. Yenidoğan bebeklerde hiperbilirubinemi ile glukoz-6 fosfat dehidrojenaz enzim eksikliği arasında ilişki. Cerrahpaşa Tıp Fakültesi Dergisi 1989;21:51-4. 